\title{
PENGEMBANGAN GAME ANIMASI INTERAKTIF PADA MATERI BANGUN RUANG SISI DATAR KELAS VIII
}

\author{
Nurin Hilmida ${ }^{1}$ \\ ${ }^{1}$ Guru Matematika SMP PGRI Beji Malang \\ Email: ${ }^{1}$ hilmida26@gmail.com
}

\begin{abstract}
Abstrak
Tujuan pengembangan ini untuk mendeskripsikan proses pengembangangame animasi interaktif pada Materi bangun ruang sisi dataruntuk siswa kelas VIII SMP,serta mendeskripsikanhasiluji coba dan validasipengembangan game animasi interaktif pada Materi bangun ruang sisi datar kelas VIII SMP. Dalam pengembangan game animasi interaktif pada Materi bangun ruang sisi datar ini pengembang mengacu pada model pengembangan four-D (4-D) yang meliputi 4 tahap, yaitu define (pendefinisian/kajian awal), design (perancangan), develop (pengembangan), dan disseminate (penyebaran). Subjek uji coba terdiri dari satu ahli materi, satu ahli media dan desain, satu praktisi,dan 6 siswa kelas VIII sebagai user/pengguna. Untuk teknik analisis data diambil dari data kuantitatif dan kualitatif. Berdasarkan data kevalidan produk, ahli materi menyatakan $77 \%$ produk cukup valid, ahli media dan desain menyatakan produk $85 \%$ valid, dan praktisi menyatakan produk $82 \%$ valid, sehingga dapat disimpulkan bahwa produk yang dihasilkan valid dengan rata-rata persentase $81,33 \%$. Sedangkan berdasarkan data kepraktisan produk, user/pengguna menyatakan produk $83 \%$, sehingga dapat disimpulkan bahwa produk yang dihasilkan dapat diterapkan di kelas dan bermanfaat bagi siswa.Kesimpulan dari hasil pengembangan tersebut adalah pengembangan game animasi interaktifini dapat membantu siswa dalam memahami dan mendalami materi bangun ruang sisi datar. Game animasi interaktif ini dapat digunakan sebagai referensi bahan ajar mandiri dalam pembelajaran matematika. Game animasi interaktif dalam pembelajaran matematika lebih praktis penggunaannya. Selain itu, dapat membuat siswa merasa senang, tidak bosan,dan termotivasi dalam mempelajari matematika terutama materi bangun ruang sisi datar.
\end{abstract}

Kata Kunci: pengembangan,multimedia interaktif, game animasi interaktif, bangun ruang sisi datar.

\section{PENDAHULUAN}

Pendidikan merupakan unsur penting dalam kehidupan, maka dari itu penyempurnaan sistem pendidikan harus terus dilakukan. Pendidikan merupakan proses penyiapan warga negara dalam suatu kegiatan yang terencana untuk membekali peserta didik agar menjadi warga negara yang baik (Husamah dkk, 2015:30). Pendidikan juga merupakan proses untuk mencapai salah satu tujuan bangsa Indonesia yang tertuang dalam Pembukaan UndangUndang Dasar 1945 alinea ke-4 yaitu mencerdaskan kehidupan bangsa. Tujuan nasional ini kemudian dijabarkan dalam Pasal 31 ayat (1) "Setiap warga negara berhak mendapat pendidikan", dan ayat (5) "Pemerintah memajukan ilmu pengetahuan dan teknologi dengan menjunjung tinggi nilai-nilai agama dan persatuan bangsa untuk kemajuan peradaban serta kesejahteraan umat manusia”. 
Amanat Undang-Undang Dasar 1945 ini dilaksanakan oleh pemerintah Republik Indonesia yakni dengan telah ditetapkannya Undang-undang Nomor 20 Tahun 2003 tentang Sistem Pendidikan Nasional. Pasal 1 ayat (1) UU No. 20 Tahun 2003 menyatakan bahwa "Pendidikan adalah usaha sadar dan terencana untuk mewujudkan suasana belajar dan proses pembelajaran agar peserta didik secara aktif mengembangkan potensi dirinya untuk memiliki kekuatan spiritual keagamaan, pengendalian diri, kepribadian, kecerdasan, akhlak mulia, serta ketrampilan yang diperlukan dirinya, masyarakat, bangsa dan negara".Jdimenurut UU No. 20 Tahun 2003 ini, peserta didik harus di dorong untuk mengembangkan potensinya untuk memiliki kekuatan spiritual keagamaan, mampu mengendalikan diri, memiliki kepribadian yang kuat, akhlak yang mulia serta keterampilan yang diperlukan dalam kehidupan bermasyarakat, berbangsa, bernegara. Pasal 1 ayat (1) ini juga mengamanatkan bahwa pelaksanaan pendidikan harus dilaksanakan pemerintah dan pemerintah daerah, bahkan juga masyarakat terencana, terpadu dan berkesinambungan.

Peranan pemerintah pusat dan daerah sangat diharapkan dapat meningkatkan kualitas pendidikan di tiap-tiap daerah tanpa pengecualian.Untuk ituPasal 11 ayat (1) menetapkan "Pemerintah dan Pemerintah Daerah wajib memberikan layanan dan kemudahan, serta menjamin terselenggaranya pendidikan yang bermutu bagi setiap warga negara tanpa diskriminasi (UU No. 20 Tahun 2003). Upaya pemerintah untuk melaksanakan amanat UUD 1945 dan UU No. 20 Tahun 2003 tersebut antara lain dengan menerapkan Teknologi Informasi dalam dunia pendidikan agar terselenggara pendidikan yang bermutu bagi setiap warga negara benar-benar terwujud. Teknologi informasi telah diatur melalui UU No. 11 Tahun 2008 tentang Informasi dan Transaksi Elektronik (ITE) di dalam Pasal 1 ayat (3) ditetapkan "Teknologi Informasi adalah suatu teknik untuk mengumpulkan, menyiapkan, menyimpan, memproses, mengumumkan, menganalisis, dan menyebarkan informasi"'(UU No. 11 Tahun 2008).

Dengan adanya teknologi informasi seakan membawa pada suatu paradigma baru mengenai upaya berinovasi dalam pendidikan untuk mencerdaskan kehidupan bangsa. Sudah selayaknya lembagapendidikan yang ada segera memperkenalkan dan memulai penggunaan teknologi informasi dan komunikasi sebagai basis pembelajaran yang lebih mutakhir.Menurut Haryoko (2009:2) Teknologi informasi dan komunikasi banyak menawarkan berbagai kemudahan dalam pembelajaran, yang memungkinkan terjadi pergeseran orientasi pembelajaran dari proses penyajian berbagai pengetahuan menjadi proses bimbingan dalam melakukan eksplorasi individual terhadap ilmu pengetahuan. Di samping itu juga memungkinkan terjadi perubahan paradigma dari filosofi pembelajaran berpusat pada guru (teacher centered) menjadi pembelajaran berpusat pada siswa (student centered).

Dalam pendidikan itu sendiri, Menurut Sujoko (2013:72) manfaat Teknologi Informasi dan Komunikasi (TIK) dikategorikan menjadi empat yaitu; pertama TIK sebagai gudang ilmu pengetahuan, dimanfaatkan sebagai referensi ilmu pengetahuan terkini, manejemen pengetahuan, jaringan pakar beragam bidang ilmu, jaringan antar instansi pendidikan, pusat pengembangan materi ajar, dan wahana pengembangan kurikulum. Kedua TIK sebagai alat bantu pembelajaran, sekurang-kurangnya ada tiga fungsi TIK yang dapat dimanfaatkan sehari-hari di dalam proses pembelajaran, yaitu (a) TIK sebagai alat bantu guru yang meliputi animasi peristiwa, alat uji siswa, sumber referensi ajar, evaluasi kinerja siswa, simulasi kasus, alat peraga visual, dan media komunikasi antar guru. (b) TIK sebagai alat bantu interaksi guru dan siswa yang meliputi komunikasi guru-siswa, kolaborasi kelompok studi, dan manejemen kelas terpadu. (c) TIK sebagai alat bantu siswa meliputi : buku interaktif, belajar mandiri, latihan soal, media ilustrasi, simulasi pelajaran, alat karya siswa, dan media komunikasi antar siswa. Ketiga TIK sebagai fasilitas pembelajaran, dimanfaatkan sebagai: perpustakaan elektronik, kelas visual, aplikasi multimedia, kelas teater multimedia, 
kelas jarak jauh, papan elektronik dan Keempat TIK sebagai infra struktur merupakan dukungan teknis dan aplikasi untuk pembelajaran baik dalam skala menengah maupun luas.

Oleh karena itu, pendidikan juga perlu memanfaatkan kemajuan ilmu pengetahuan dan teknologi agar mampu mencapaitujuan pendidikan secara efektif dan efisien.Guna meningkatkan efektivitas dan efisiensi pembelajaran, perlu dikembangkan berbagai model pembelajaran yang kreatif dan inovatif. Hal ini perlu dilakukan agar proses pembelajaran menjadi menarik, tidak monoton dan tidak membosankan.Dengan kata lain kemajuan teknologi dapat dimanfaatkan sebagai media pembelajaran yang menarik untuk meningkatkan kualitas pembelajaran. Multimedia interaktif (MMI) merupakan salah satu model pembelajaran yang menarik berbasis teknologi. Menurut Munir (2013:115) Model pembelajaran multimedia interaktif (MMI) diartikan sebagai suatu model pembelajaran yang dapat digunakan untuk menyalurkan pesan (message), merangsang pikiran, perasaan, perhatian dan kemauan siswa sehingga dapat mendorong proses belajar.

Pada hakikatnya pembelajaran merupakan proses komunikasi yang bertujuan untuk penyampaian pesan/informasi sehingga dapat merangsang pikiran, perasaan dan minat serta perhatian peserta didik. Dalam proses pembelajaran, pengembangan materi/bahan ajar dapat melalui berbagai cara, salah satunya adalah pengembangan bahan ajar melalui optimalisasi media. Media yang digunakan untuk memperlancar proses pembelajaran seringkali disebut media pembelajaran. Salah satu upaya pengembang dalam meningkatkan kualitas pembelajaran melalui media pembelajaran berbasis teknologi informasi dan komunikasi dalam pembelajaran matematika.

Berdasarkan hasil analisis yang dilakukan di SMP PGRI Beji, media pembelajaran berbasis teknologi informasi dan komunikasi sebelumnya sudah ada namun hanya menunjukkan teori saja. Berdasarkan hal tersebut dilakukan analisis angket kebutuhan guru dan angket kebutuhan siswa. Dari hal tersebut dapat diperoleh hasil analisis angket kebutuhan guru yang menunjukkan bahwa 100\% guru mengatakan sangat setuju memerlukan bahan ajar elektronik dalam proses pembelajaran matematika. Sedangkan berdasarkan hasil analisis kebutuhan siswa yang dilakukan terhadap siswa kelas VIII di SMP PGRI Beji, 31\% siswa juga menyatakan sangat setuju dan 58\% menyatakan setuju jika dalam kegiatan pembelajaran matematika di kelas guru menggunakan bahan ajar pendukung yang inovatif.

Berdasarkan hal tersebut dapat disimpulkan bahwa guru memerlukan bahan ajar yang lebih bervariasi dengan ditunjang bahan ajar elektronik, selain itu siswa juga menginginkan adanya bahan ajar yang inovatif.Oleh karena itu dikembangkan media penunjang berupa game animasi interaktif dengan berbantu Adobe Flash dan 3Dmax agar proses visualisasi pembelajaran matematika pokok bahasan bangun ruang sisi datar terlihat lebih nyata dan interaktif yang dapat membantu guru dalam meningkatkan minat dan pemahaman siswa.

\section{METODE}

Pengembangan ini bertujuan untuk mengembangkan dan menghasilkan media pembelajaran game animasi interaktif pada materi bangun ruang sisi datar kelas VIII SMP PGRI Beji. Model pengembangan yang digunakan adalah model pengembangan 4-D. Model 4-D ini dipilih karena model pengembangan ini disusun secara terprogram yang disertai dengan urutan kegiatan yang sistematis, praktis, dan mudah digunakan. Menurut Thiagarajan, dkk (dalam Trianto, 2017:93) model pengembangan perangkat yang disarankan adalah Model 4-D. Model Four-D (4-D) memiliki empat tahap utama yaitu: (1) Define (Pendefinisian/Kajian Awal), (2) Design (Perancangan), (3) Develop (Pengembangan), dan (4) Disseminate (Penyebaran). 


\section{HASIL}

Hasil dari pengembangan ini berupa produk game animasi interaktif untuk siswa SMP PGRI Beji kelas VIII pada materi bangun ruang sisi datar. Game animasi interaktif tersebut dihasilkan melalui langkah-langkah pengembangan yang akan dijelaskan sebagai berikut.

\section{Analisis Data Hasil Validasi Ahli Materi}

Analisis data hasil validasi ahli materi dilakukan dari analisis penilaian ahli terhadap materi dalam game animasi interaktif untuk pembelajaran matematika. Setelah mendapatkan skor dari ahli, selanjutnya dianalisis per aspek dengan menghitung skor ratarata tiap aspeknya. Tabel 4.19 dan Gambar 4.18 adalah analisis data validasi ahli materi beserta kategori kevalidannya serta hasil analisis ahli materi.

Tabel 4.19 Analisis Data Hasil Validasi Ahli Materi

\begin{tabular}{ccc}
\hline Aspek & $\boldsymbol{P}=\frac{\sum \boldsymbol{X}}{\boldsymbol{N}}(\%)$ & Kriteria Kevalidan \\
\hline Aspek Materi & 75 & Cukup valid \\
\hline Aspek Soal Latihan & 75 & Cukup Valid \\
\hline Aspek Kebahasaan & 85 & Valid \\
\hline Aspek Tampilan dan Grafis & 75 & Cukup Valid \\
\hline Aspek Pembelajaran & 75 & Cukup Valid \\
\hline $\boldsymbol{N A}=\frac{2 \boldsymbol{P}}{\boldsymbol{n}}$ & $\mathbf{7 7}$ & Cukup Valid \\
\hline
\end{tabular}

Berdasarkan analisis hasil validasi materi pada Tabel 4.19, game animasi interaktif untuk pembelajaran matematika dikembangkan cukup valid dengan persentase kevalidan sebesar $77 \%$.

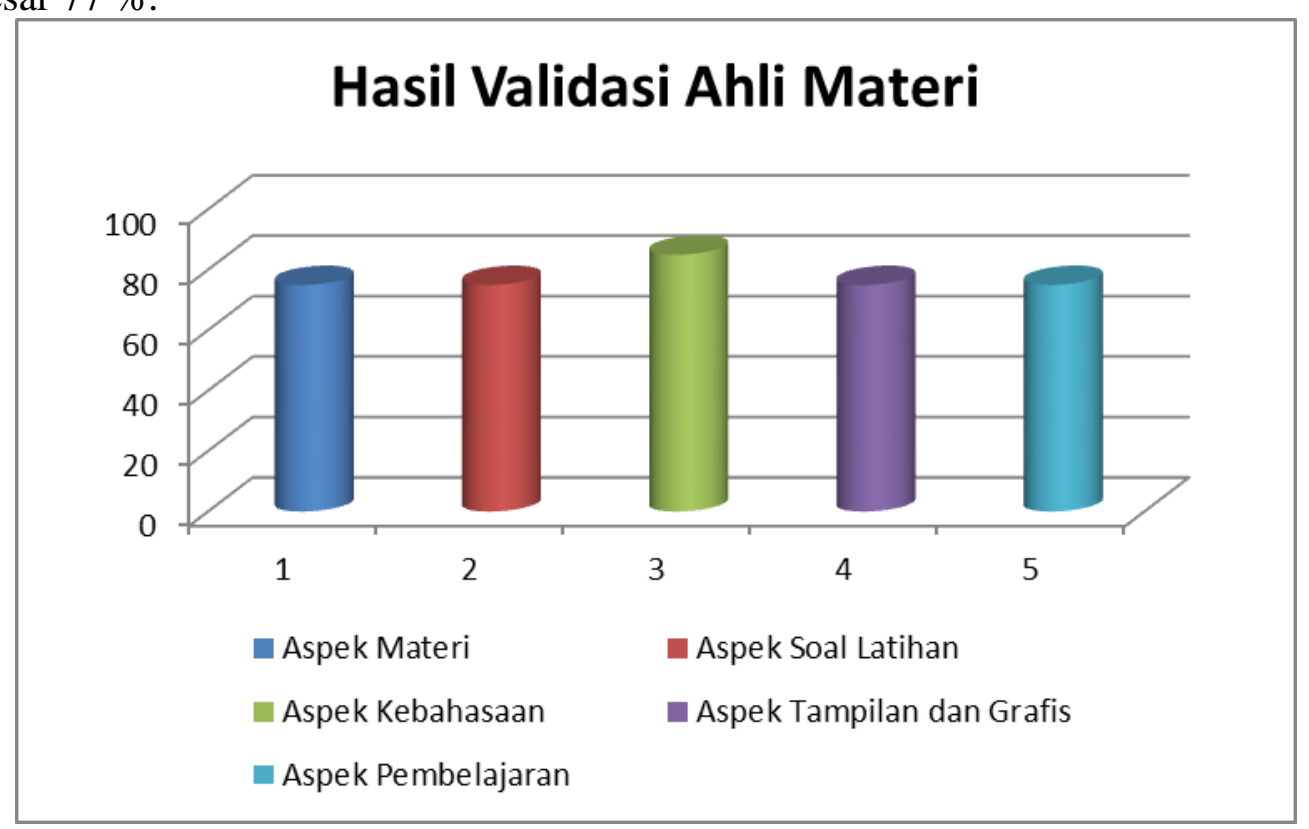

Gambar 4.18 Hasil Analisis Validasi Ahli Materi

Berdasarkan grafik pada Gambar 4.18, dapat dijelaskan bahwa aspek kualitas materi, aspek kualitas latihan soal dan aspek kualitas bahasa cukup valid dengan persentase kevalidan masing-masing sebesar 77\%. Aspek tampilan dan grafis memiliki kriteria cukup valid dengan persentase kevalidan $75 \%$ sedangkan aspek pembelajaran dijelaskan cukup valid dengan nilai kevalidan $75 \%$. 


\section{Analisis Data Hasil Validasi Ahli Media dan Desain}

Analisis data hasil validasi ahli media dilakukan dari analisis penilaian ahli terhadap game animasi interaktif untuk pembelajaran matematika. Setelah mendapatkan skor dari ahli, selanjutnya dianalisis per aspek dengan menghitung skor rata-rata tiap aspeknya. Hasil analisis data validasi ahli media dengan kategori kevalidannya dapat dilihat pada Tabel 4.20 dan Gambar 4.19.

Tabel 4.20 Analisis Data Validasi Ahli Media dan Desain

\begin{tabular}{ccc}
\hline Aspek & $\boldsymbol{P}=\frac{\sum X}{\boldsymbol{N}}(\%)$ & Kriteria Kevalidan \\
\hline Aspek Tampilan & 94 & Sangat Valid \\
\hline Aspek Pemrograman & 85 & Valid \\
\hline Aspek Bahasa & 67 & Kurang Valid \\
\hline Aspek Pembelajaran & 94 & SangatValid \\
\hline $\boldsymbol{N}=\frac{\sum \boldsymbol{P}}{\boldsymbol{n}}$ & 85 & Valid \\
\hline
\end{tabular}

Berdasarkan analisis hasil validasi media dan desain pada Tabel 4.20, game animasi interaktif untuk pembelajaran matematika dikembangkan valid dengan persentase kevalidan sebesar $85 \%$.

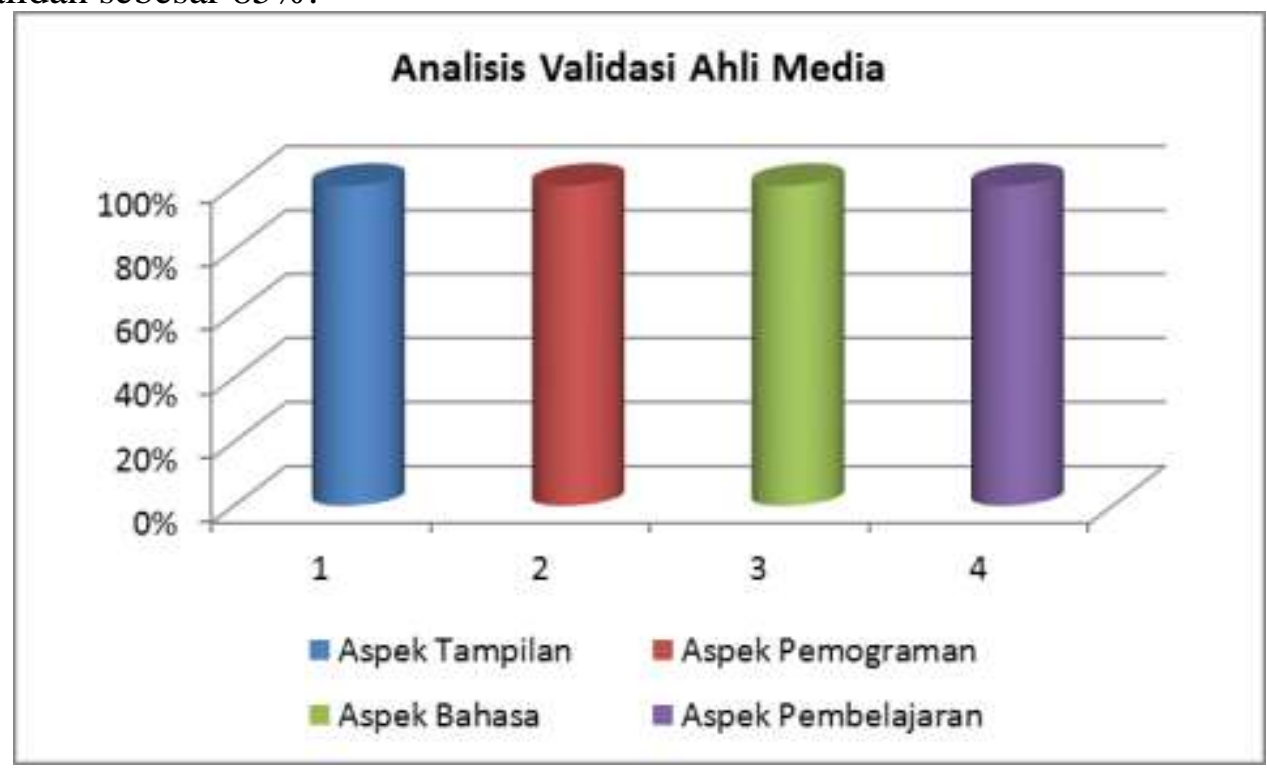

Gambar 4.19 Hasil Analisis Validasi Ahli Media dan Desain

Berdasarkan grafik pada Gambar 4.19, dapat dijelaskan bahwa aspek tampilan sangat valid dengan persentase kevalidan sebesar 94\%, aspek pemrograman sangat valid dengan persentase kevalidan sebesar $85 \%$, bahasa valid dengan persentase kevalidan sebesar $67 \%$, dan aspek pembelajaran sangat valid dengan persentase kevalidan $94 \%$.

\section{Analisis Data Hasil Validasi Praktisi}

Selain dinilai oleh ahli, game animasi interaktif untuk pembelajaran matematika juga dinilai oleh praktisi. Praktisi memberikan penilaian game animasi interaktif untuk mengetahui kevalidan dari game animasi interaktif, kemudian dianalisis per aspek dengan menghitung persentase skor tiap aspek-aspeknya.Tabel 4.22 dan Gambar 4.20 adalah hasil analisis data telaah praktisi beserta kriteria kevalidannya.

Tabel 4.22 Analisis Data Validasi Praktisi

\begin{tabular}{ccc}
\hline Aspek & $\boldsymbol{P}=\frac{\sum X}{\boldsymbol{N}}(\%)$ & Kriteria Kevalidan \\
\hline Aspek Materi & 96 & Sangat Valid \\
\hline Aspek Teknis & 81 & Valid \\
\hline
\end{tabular}




\begin{tabular}{ccc}
\hline Aspek Bahasa & 75 & Cukup Valid \\
\hline Aspek Tampilan & 75 & Sangat Valid \\
\hline Aspek Penggunaan & 83 & Valid \\
\hline $\boldsymbol{N A}=\frac{2 \boldsymbol{P}}{\boldsymbol{n}}$ & 82 & Valid \\
\hline
\end{tabular}

Berdasarkan analisis hasil validasi praktisi pada Tabel 4.22, game animasi interaktif untuk pembelajaran matematika dikembangkan valid dengan persentase kevalidan sebesar $82 \%$.

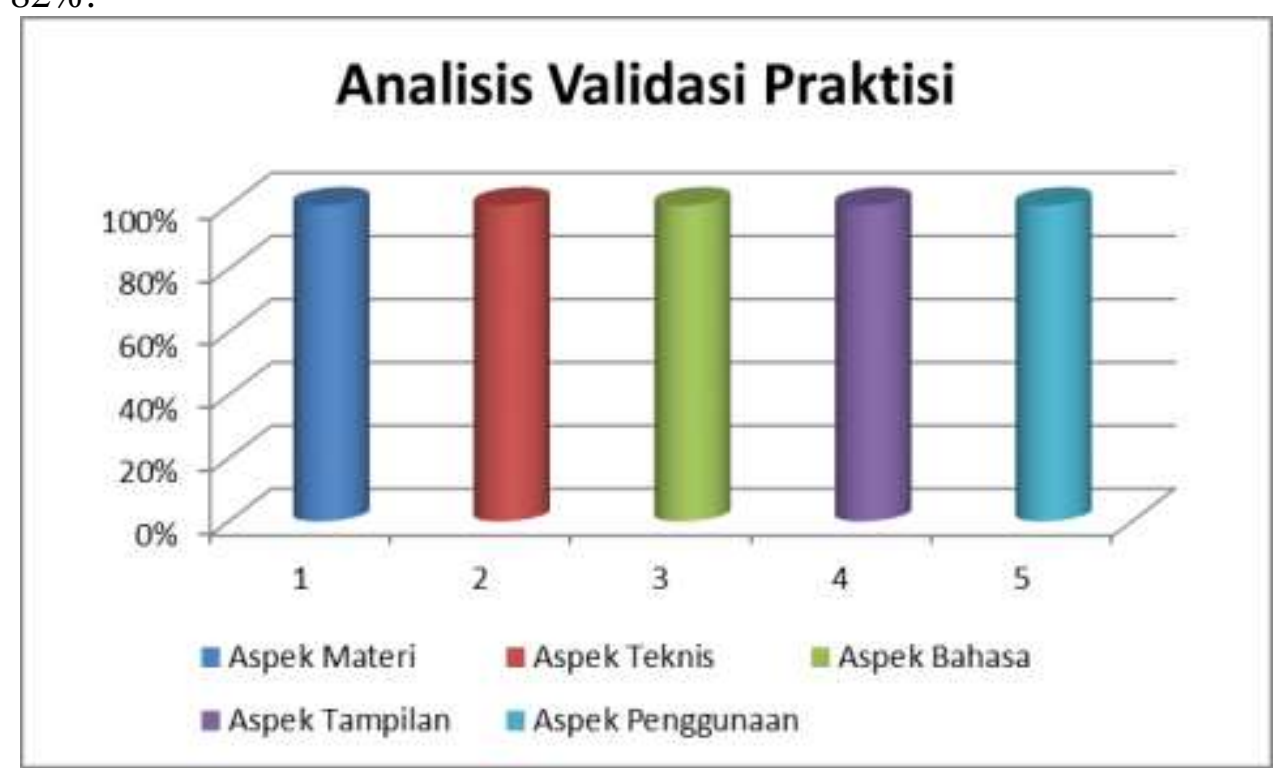

Gambar 4.20 Hasil Analisis Validasi Praktisi

Berdasarkan grafik pada Gambar 4.20, dapat dijelaskan bahwa aspek materi sangat valid dengan persentase kevalidan sebesar 96\%, aspek teknis valid dengan persentase kevalidan sebesar $81 \%$, aspek bahasa cukup valid dengan persentase kevalidan sebesar $75 \%$, aspek tampilan cukup valid dengan persentase kevalidan sebesar $75 \%$, dan aspek penggunaan valid dengan persentase kevalidan $83 \%$.

4. Analisis Data Hasil Uji Coba Pengguna/User

Setelah divalidasi oleh validator ahli dan praktisi, serta memenuhi kriteria kevalidan, game animasi interaktif untuk pembelajaran matematika yang dikembangkan dapat diujicobakan kepada pengguna/user. Uji coba ini dilakukan untuk mengetahui game animasi interaktif untuk pembelajaran matematika pada materi bangun ruang sisi datar. Dalam pengembangan ini, subjek uji coba adalah 6 siswa kelas VIII SMP PGRI Beji. Hasil analisis uji coba user beserta persentase skor penilaian per aspek disajikan pada Tabel 4.23 dan Gambar 4.21.

Tabel 4.23Analisis Data Hasil Uji Coba Pengguna/User

\begin{tabular}{lcccccccc}
\hline Aspek & \multicolumn{1}{c}{ Skor Pengguna/User $(\boldsymbol{\%})$} & & $\begin{array}{l}\text { Rata- } \\
\text { Rata }\end{array}$ & $\begin{array}{l}\text { Kriteria } \\
\text { Keprakti } \\
\text { s-an }\end{array}$ \\
\cline { 2 - 9 } & $\mathbf{1}$ & $\mathbf{2}$ & $\mathbf{3}$ & $\mathbf{4}$ & $\mathbf{5}$ & $\mathbf{6}$ & & \\
\hline $\begin{array}{l}\text { Kualitas Isi } \\
\text { dan Tujuan }\end{array}$ & 92 & 83 & 83 & 92 & 96 & 79 & $88 \%$ & Praktis \\
\hline Bahasa & 83 & 67 & 75 & 83 & 75 & 75 & $76 \%$ & $\begin{array}{l}\text { Cukup } \\
\text { Praktis }\end{array}$ \\
\hline Tampilan & 79 & 75 & 92 & 83 & 88 & 100 & $86 \%$ & Praktis \\
\hline Kesimpulan & & & & & & & $\mathbf{8 3 \%}$ & Praktis \\
\hline
\end{tabular}


Dari analisis data hasil uji coba pengguna dapat ditampilkan dalam bentuk grafik pada gambar grafik 4.21 berikut.

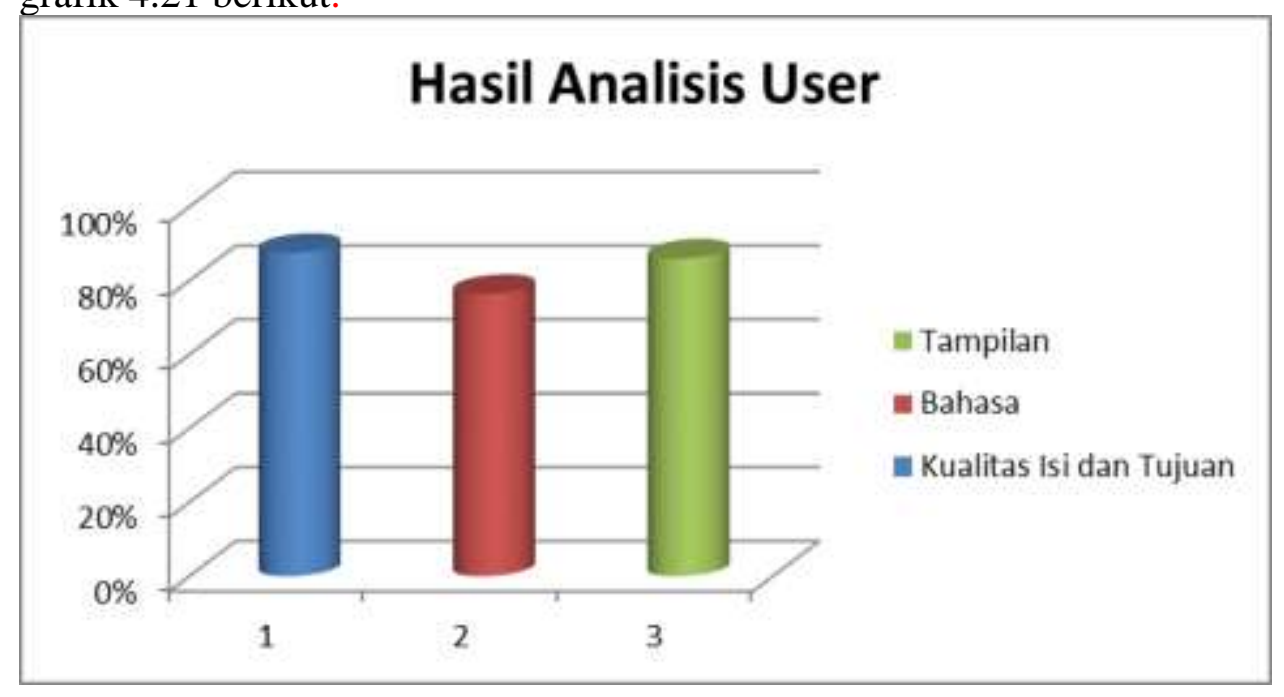

Gambar 4.21 Hasil Analisis Uji Coba User

Berdasarkan hasil analisis uji coba user pada 6 siswa kelas VIII tersebut menunjukkan bahwa game animasi interaktif untuk pembelajaran matematika memiliki kriteria praktis dengan skor $83 \%$ dapat digunakan pada kelas yang lebih luas.

Hasil analisis berdasarkan perhitungan (diadaptasi dari Sugiyono, 2014:137 dari ahli materi adalah $77 \%$, ahli media dan desain adalah $85 \%$. Hasil analisis validasi praktisi diperoleh skor 82\%, sehingga dapat diketahui bahwa game animasi interaktif untuk pembelajaran matematika yang dikembangkan memiliki kriteria yang valid. Sedangkan analisis data hasil uji coba 6 siswa kelas VIII SMP PGRI Beji adalah 83\% dan praktis digunakan. Data persentase penilaian yang diperoleh data verbal deskriptif dengan menggunakan kriteria yang disajikan (diadaptasi dari Sudjana, 2009:124). Dari data tersebut dapat disimpulkan bahwa game animasi interaktif untuk pembelajaran ini layak digunakan.

\section{PEMBAHASAN}

Berdasarkan pengertian tersebut game animasi interaktif merupakan permainan dengan animasi-animasi untuk memvisualisasikan objek dan dalam permainannya terjadi hubungan antara user dan perantara komputer. Penyusunan game animasi interaktifuntuk pembelajaranini menggunakan tahapan-tahapan model pengembangan 4-D (four $D$ )seperti yang disarankan oleh Thigarajan dkk (dalam Trianto, 2017: 93). Model ini terdiri dari 4 tahapan yaitu define (pendefinisian), design (perancangan), develop (pengembangan), dan disseminate (penyebaran).

Hasil pengembangan adalah berupa game animasi interaktifuntuk pembelajaranyang dilengkapi rumusan materi,latihan soal,uji kompetensi. Dengan menggunakan game animasi interaktifuntuk pembelajaran, siswa dapat lebih meningkatkan pemahaman materi bangun ruang sisi datar yang ada pada game animasi interaktif untuk pembelajaran ini telah divalidasi oleh validator ahli materi, validator ahli media dan desain, validator praktisi, dan validator pengguna/user (siswa).Aspek yang dinilai oleh validator ahli materimeliputi materi, latihan soal, bahasa, tampilan dan pembelajaran.Validator ahli media dan desain menilaiaspek sistematika, aspek tampilan, aspek pembelajaran, dan aspek pemograman.Sedangkan validator praktisi menilai aspek kualitas isi dari materi, teknis, bahasa, tampilan dan penggunaan.Pengguna/user memberikan penilaian tentang kualitas isi, aspek bahasa dantampilan. 
Hasil analisis berdasarkan perhitungan (diadaptasi dari Sugiyono, 2014:137 dari ahli materi adalah $77 \%$, ahli media dan desain adalah $85 \%$. Hasil analisis validasi praktisi diperoleh skor $82 \%$, sehingga dapat diketahui bahwa game animasi interaktifuntuk pembelajaranmatematika yang dikembangkan memiliki kriteria yang valid. Sedangkan analisis data hasil uji coba 6 siswa kelas VIIISMP PGRI Bejiadalah 83\% dan praktis digunakan. Data persentase penilaian yang diperoleh data verbal deskriptif dengan menggunakan kriteria yang disajikan (diadaptasi dari Sudjana, 2009:124). Dari data tersebut dapat disimpulkan bahwa game animasi interaktifuntuk pembelajaran ini layak digunakan.

\section{SIMPULAN DAN SARAN}

Berdasarkan hasil pengembangan dan pembahasan pada penelitian pengembangan game animasi interaktif pada materi bangun ruang sisi datar untuk siswa kelas kelas VIII SMP, dapat disimpulkan sebagai berikut:

1. Pengembangan game animasi interaktif ini menggunakan model Four-D (4-D). Model ini terdiri dari empat tahap.

1) Tahap Define (KajianAwal)

Analisis Ujung depan merupakan proses mengidentifikasi kebutuhan guru dan kebutuhan siswa.Pada tahap ini pengembang mengambil sampel guru dari SMP PGRI Beji. Dalam proses analisis kebutuhan, pengembang mengambil sampel dengan cara menyebar angket kebutuhan siswa untuk dianalisi ssebanyak 45 siswa dan 2 angket kebutuhan guru dari sekolah tersebut.

2) Design (Perancangan)

Membuat Desain game animasi interaktif dalam bentuk Flowchart dan Storyboard

a. Membuat Flowchart

b. Membuat Story Board atau Lembar Presentasi pada Kertas

c. Penyusunan Materi Bangun Ruang Sisi Datar

3) Develop (Pengembangan)

Pada tahap develop (pengembangan) ini, game animasi interaktif awal atau draf ke-I akan dilakukan validasi oleh tiga validator, yaitu.

a. Satu validator ahli materi matematika

b. Satu validator ahli media dan desain game animasi interaktif

c. Satu validator praktisi

Setelahtiga validator memvalidasi game animasi interaktif awal atau draf ke-I, peneliti menganalisis angket penilaian game animasi interaktif yang telah diberikan kepada validator. Jika game animasi interaktif awal atau draf ke-I valid, maka pengembang bias melakukan uji coba game animasi interaktif kepada kelompok kecil (enam siswa). Tetapi jika belum valid, maka pengembang harus melakukan revisi terlebih dahulu, kemudian dikembalikan kepada validator kembali dan jika sudah valid, game animasi interaktif draf ke-II akan disebar kepada kelompok kecil (enam siswa) untuk diuji coba.

4) Disseminate (Penyebaran)

Tahap ini merupakan tahap penggunaan produk (game animasi interaktif) yang telah dikembangkan pada skala yang lebih luas misalnya di kelaslain, di sekolah lain, dan oleh guru yang lain. Pada tahap ini produk yang dihasilkan sudah berupa produk akhir yaitu game animasi interaktif untuk siswa SMP kelas VIII di SMP PGRI Beji pada materi bangun ruang sisi datar.

2. Ketepatan produk pengembangan ini disimpulkan berdasarkan hasil penilaian dari beberapa validator berikut ini. 
a. Ahli Media dan Desain

Menurut ahli media, aspek produk yang sudah dikembangkan game animasi interaktif pada materi bangun ruang sisi datar untuk siswa kelas VIII $85 \%$ dengan criteria kevalidan adalah sangat valid.

b. Ahli Materi

Menurut ahli materi, aspek produk yang sudah dikembangkan game animasi interaktif pada materi bangun ruang sisi datar untuk siswa kelas VIII 77\% dengan criteria kevalidan adalah cukup valid.

c. Ahli Praktisi

Menurut ahli praktisi, aspek produk yang sudah dikembangkan pada game animasi interaktif pada materi bangun ruang sisi datar untuk siswa kelas VIII 82\% dengan criteria kevalidan adalah valid.

d. Respon siswa (User)

Menurut respon siswa (user), aspek produk yang sudah dikembangkan pada game animasi interaktif pada materi bangun ruang sisi datar untuk siswa kelas VIII $83 \%$ dengan criteria kevalidan adalah Valid.

\section{UCAPAN TERIMA KASIH}

Ucapan terima kasih saya sampaikan kepada rektor Universitas Islam Malang, Dekan FKIP Universitas Islam Malang, Dosen Pembimbing Skripsi, pengelola JPM (Jurnal Pendidikan matematka), dan kedua orang tua, saudara, sahabat, dan teman-teman jurusan pendidikan matematika, serta pihak-pihak yang ikut serta membantu penyusunan artikel ini.

\section{DAFTAR RUJUKAN}

Haryoko, S. (2009). Efektivitas Pemanfaatan Media Audio-Visual Sebagai Alternatif Optimalisasi Model Pembelajaran. Jurnal Edukasi, 5(1), 1-10.

Husamah. (2015). Pengantar Pendidikan. Malang: UMM PRESS.

Naskah Undang-Undang Dasar 1945 Hasil Amandemen. Yogyakarta: Andi Offset.

Peraturan Menteri Pendidikan Nasional Republik Indonesia Nomor 20 Tahun 2003 tentang Sistem Pendidikan Nasional. (2003). Jakarta: Departemen Pendidikan Nasional.

Peraturan Menteri Pendidikan Nasional Republik Indonesia Nomor 11 Tahun 2008 tentang

Informasi dan Transaksi Elektronik. (2008). Jakarta: Departemen Pendidikan Nasional.

Setyosari, P. (2016). Metode Penelitian Pendidikan dan Pengembangan. Jakarta: Prenada Media Group.

Sujoko. (2013). Pemanfaatan Teknologi Informasi dan Komunikasi sebagai Media Pembelajaran di SMP Negeri 1 Geger Madiun. Jurnal Kebijakan dan Pengembangan Pendidikan, 1(1), 71-77

Trianto. (2017). Model Pembelajaran Terpadu konsep,Strategi, dan Implementasinya dalam kurikulum tingkat satuan pendidikan (KTSP). Jakarta: Bumi Aksara. 